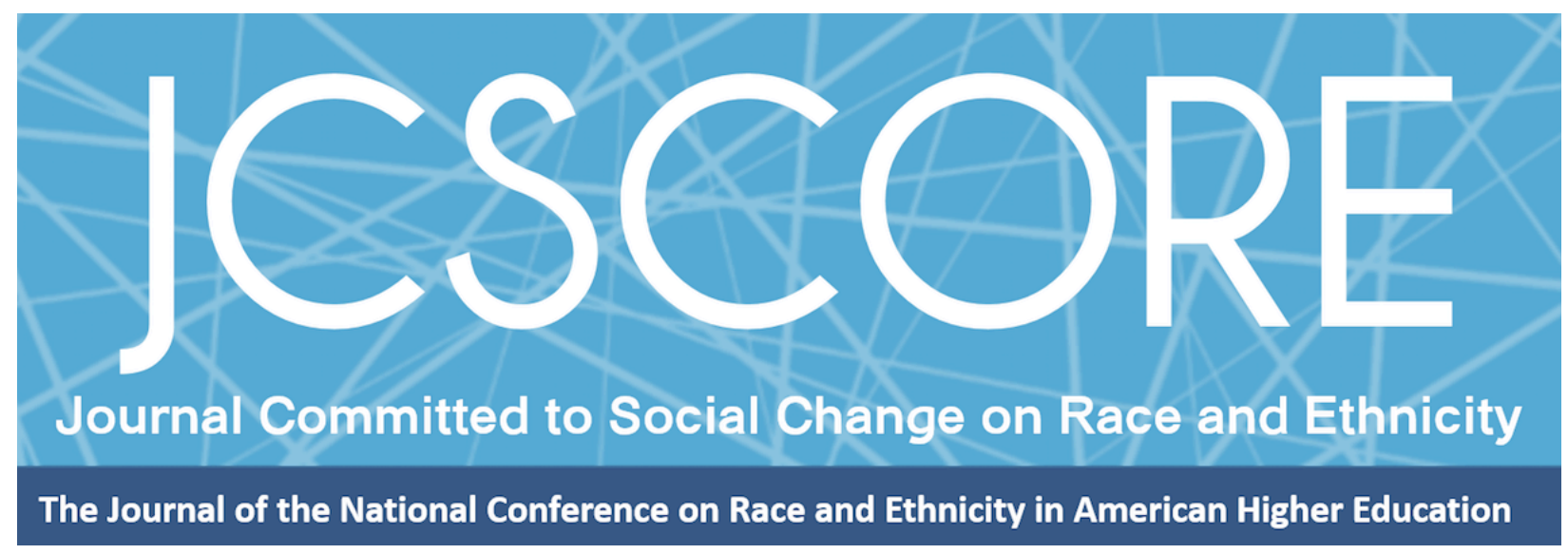

\title{
HOW HIGH-IMPACT PRACTICES INFLUENCE ACADEMIC ACHIEVEMENT FOR AFRICAN AMERICAN COLLEGE STUDENTS
}

John Gipson

Purdue University

Donald Mitchell Jr.

Bellarmine University

Journal Committed to Social Change on Race and Ethnicity

Volume 3, Issue 2 | 2017

Copyright $\odot 2017$ Board of Regents of The University of Oklahoma on behalf of the Southwest Center for Human Relations Studies.

Permission of the Publisher is required for resale or distribution and for all derivative works, including compilations and translations. Quoting small sections of text is allowed as long as there is appropriate attribution. 


\title{
How High-Impact Practices Influence Academic Achievement for African American College Students
}

\author{
John Gipson \\ Purdue University \\ Donald Mitchell Jr. \\ Bellarmine University
}

Utilizing data from seven four-year public institutions in the United States, this study employed chi-square test for independence and a Mann-Whitney $U$ test to examine the relationships between participation in high-impact practices (HIPs) and academic outcomes of undergraduate African American college students. Findings suggest the number of HIPs undergraduate African American students were involved in was associated with academic achievement. Furthermore, associations between HIPs and academic achievement differed based on class standing (i.e., first-year/second-year and junior/senior) and gender. The article closes with implications for practice and future research.

Low retention and graduation rates for African American students are persistent, despite increased postsecondary access (Cuyjet, 2006; DeAngelo, Franke, Hurtado, Pryor, \& Tran, 2011; Rovai, Gallien, \& Wighting, 2005; Wilson, 2007). It is well documented that many precollege characteristics which often stand in the way of collegiate success are more likely to impact African American students in comparison to other racial/ethnic peers, particularly their White student counterparts (Choy, 2001; Mauk \& Jones, 2006; Smith, 2009). Characteristics associated with first-generation college status (Choy, 2001), low socioeconomics (Smith, 2009), lack of knowledge about the college environment (Vargas, 2004), and academic underpreparation for

\footnotetext{
Research reported in this publication was supported by Grand Valley State University's Center for Creative and Scholarly Excellence. The content is solely the responsibility of the authors and does not represent the views of Grand Valley State University's Center for Creative and Scholarly Excellence.
} 
college (ACT, 2011; Thomas et al., 2007) are often linked with their K-12 school district's zip code. Nevertheless, institutions of higher education cannot control these characteristics and must support African American students once enrolled.

According to Pascarella and Terenzini (2005), African American students choose to leave institutions of higher education when they are not provided with adequate support. Contrary to these data, some African American students persist and achieve their goals of a postsecondary degree. As such, scholars have begun documenting the successes of African American students because many do, in fact, succeed (e.g., see Bonner, 2010; Fries-Britt \& Griffin, 2007; Griffin, 2006; Guiffrida, 2004a, 2004b; Harper, 2005, 2008, 2012; Harper \& Griffin, 2011). Illustrating the need for additional research on African American students and documenting factors associated with achievement, Harper (2012) noted, "[T]he popular one-sided emphasis on failure and low performing Black male undergraduates must be counterbalanced with insights gathered from those who somehow manage to navigate their way to and through higher education, despite all that is stacked against them" (p. 1). While Harper's work has primarily focused on Black males ${ }^{1}$, his clarion call rings true for all African American students.

Other scholars have also recognized the need to document successes of highachieving African American college students (HAAACSs) and studies regarding the experiences of HAAACSs continue to emerge, using anti-deficit and success narratives rather than failure and dropout (e.g., see Bonner, 2010; Fries-Britt \& Griffin, 2007; Griffin, 2006; Guiffrida, 2004a, 2004b; Harper, 2005, 2008, 2012; Harper \& Griffin,

${ }^{1}$ While our study uses gender identity constructs, male and men and female and women are used interchangeably throughout the article to align with what authors used in their original works. 
2011). Still, there is room to further document the successes of African American students as existing studies have often used qualitative methodologies.

The purpose of this study was to investigate the relationships between participation in high-impact educational practices (HIPs) and strong academic performance by undergraduate African American college students. Toward this end, high-achieving is defined as a student with a grade point average (GPA) greater than 3.0, a threshold used in previous studies (e.g., Guiffrida, 2004a; Harper, 2005, 2008, 2012). The three primary questions guiding this research were:

1. Is the number of HIPs related to academic achievement of African American college students?

2. Do HIPs impact the GPA of first-year and second-year students differently than juniors and seniors?

3. Does involvement in HIPs vary by gender identity?

\section{Theoretical Framework}

Guiffrida's (2006) cultural improvement of Tinto's model of dropout from college served as the theoretical framework for this study. Guiffrida argues that involvement in extracurricular activities, academic performance, interactions with faculty, and intrinsic/extrinsic motivation, among other factors, are important to persistence for minoritized $^{2}$ college students. Furthermore, Guiffrida prefers to utilize the term connection in place of integration stating that:

integration implies that students must become socialized into the dominant culture of the institution while abandoning their former cultures, but connection

${ }^{2}$ Similar to Harper and Griffin (2011), we use the term minoritized rather than minority to highlight race as a social construction in the United States and that certain groups are minoritized because of White privilege. 
recognizes students' subjective sense of relatedness without implying the need to break ties with one's former community. This subtle yet important change allows the theory to recognize that students can become comfortable in the college environment without abandoning supportive relationships at home or rejecting the values and norms of their home communities. (p. 457)

For the purpose of this study, we focus on the aspects of extracurricular activities and academic involvement.

\section{Involvement}

For decades scholars have documented that college student involvement matters. Astin $(1984,1999)$ describes involvement as "the amount of physical and psychological energy that the student devotes to the academic experience" (p. 518). Furthermore, literature (e.g., Astin 1984, 1999; Kuh, Kinzie, Schuh, Witt, \& Associates, 2010; Pascarella \& Terenzini, 2005) has stated that the amount of time and effort students place on activities to encourage academic success matters during college. Research suggests that involvement in campus organizations can positively influence persistent to graduation (Astin, 1984, 1999; Kuh et al., 2010; Pascarella \& Terenzini, 2005; Tinto 2006-2007). Many researchers (e.g., Guiffrida, 2004b; Harper \& Quaye, 2007; Littleton, 2002; Sutton \& Kimbrough, 2001) have determined that involvement most frequently occurs in cultural student organizations for African American college students. This may be explained by findings that members of this population are more comfortable interacting with fellow students who identify as African American than members of other student populations (Fischer, 2007; Thomas et al., 2007), especially in the context of attending a Predominantly White Institution (PWI). Relating to peer support, researchers have found that interaction with peers play a critical role in 
Journal Committed to Social Change on Race and Ethnicity | 2017

academic high-achievement for students of color (e.g., Dennis, Phinney, \& Chuateco, 2005; Harper, 2005).

Faculty involvement has been another factor that researchers have constantly found to benefit student academic success across all students (Astin, 1984, 1999; Chickering \& Gamson, 1999; Pascarella \& Terenzini, 2005; Tinto, 1975, 2006-2007) and African American students in particular (Booker, 2007; Cole, 2011; Fischer, 2007; Littleton, 2002; Thomas et al., 2007). Astin $(1984,1999)$ describes faculty-student interaction as the most critical component regarding one's satisfaction with college and Tinto (1975) states that involvement with faculty is critical to integration within the college environment. Furthermore, Littleton (2002) found that faculty involvement was the most crucial factor for persistence to graduation for African American college students.

\section{High-Impact Practices}

HIPs are activities that often combine best practices in involvement and engagement. According to Kuh (2008), HIPs are activities that "increase rates of student retention and student engagement" (p. 9) and provide great benefit to student learning and personal development throughout undergraduate education. Finley and McNair (2013) found that involvement in HIPs is beneficial to the belief one experiences deep learning, gains in general education, practical competence, and personal/social development for underserved populations; they also found that participating in HIPs has a cumulative effect in that the desirable effects were positively related to the number of HIPs students completed According to Kuh, HIPs include common intellectual experiences, learning communities, writing-intensive courses, service learning, 
Journal Committed to Social Change on Race and Ethnicity | 2017

undergraduate research, cohort-based programs, collaborative assignments/projects, diversity/global learning, first-year seminars/experiences, and capstone courses/projects. Many of these high-impact practices are linked to higher academic achievement as "students who use these approaches tend to earn higher grades and retain, integrate, and transfer information at higher rates" (Kuh, 2008, p. 14).

\section{Grade Point Average}

It is well documented that grades and persistence are positively linked for all students (Hu \& St. John, 2001; Nora, Barlow, \& Crisp, 2005; Nora, Cabrera, Hagedorn, \& Pascarella, 1996). What makes this relationship troublesome is that on average African American college students, as a group, tend to have the lowest average GPA (Fischer, 2007).

While research has shown social and academic involvement to be beneficial during the college experience, little research has been conducted to examine the experiences, particularly in HIPs, that influence academic high achievement for African American college students. Furthermore, research across sex and gender and linking academic outcomes with Kuh's (2008) HIPs is limited for undergraduate African American students. This study aims to investigate some of the gaps in high-achieving African American student literature.

\section{Method}

This study utilized a survey instrument designed by the researchers to investigate characteristics of undergraduate African American college students attending seven four-year public institutions across the United States; as defined by the Carnegie Classification of Institutions of Higher Education, four master's colleges and 
Journal Committed to Social Change on Race and Ethnicity | 2017

universities as well as three doctoral-granting universities agreed to participate in the study. The institutions ranged in size from 9,501 students to 38,770 . The survey was developed following an extensive review of literature relating to the experiences of African American college students and related survey instruments (e.g., National Survey of Student Engagement, Cooperative Institutional Research Program surveys). Content validity of the initial version of the survey was established through an extensive literature review as well as consulting senior-level student affairs administrators and faculty members on relatedness of questions to experiences available across institutions.

After consultation and revision, the instrument was piloted with a sample of 16 students to determine the inter-rater reliability of the questions. The researchers found that all of the questions but one scored greater than .60 (ranging from .76 to .985 ), which is generally acceptable when using categorical data in the social sciences (Landis \& Koch, 1977); the remaining item received a score of .562.

\section{Sample}

A purposive sample of undergraduate students who self-identified in each participating institution's record system as African American was invited to participate in the study. An invitation to participate was sent by participating institutions and a reminder was sent one week later.

The sample consisted of 652 undergraduate African American students. Of the sample, 313 students (48\%) identified as first-year or second-year status while 339 (52\%) identified as juniors or seniors. Further, 294 (45\%) participants attended research institutions, 333 (51\%) attended masters-level institutions, and 25 (4\%) 
Journal Committed to Social Change on Race and Ethnicity | 2017

students declined to identify their institution. Relating to first-generation college status, 160 participants (25\%) of students identified that neither of their parents/guardians attended a college or university, $259(40 \%)$ identified that one parent/guardian attended a college or university, $225(35 \%)$ identified that both parents/guardians attended a college or university, and eight (1\%) students elected not to respond; due to rounding, these values do not equal $100 \%$. In addition, $519(80 \%)$ students were between the ages of 18 and 23, $53(8 \%)$ were between the ages of 24 and 29, $78(12 \%)$ were age 30 or above, and two students declined to answer. Lastly, 152 (23\%) of students identified as men, $496(76 \%)$ identified as women, three (1\%) identified as transgender, and one student identified their gender as other, but did not complete the open-ended response option.

\section{Data Analysis}

Due to the categorical nature of the data, chi-square test for independence analyses were used to investigate associations between involvement in high-impact practices $(0=$ no and $1=$ yes $)$ and GPA $(0=$ less than or equal to 3.00 and $1=$ greater than or equal to 3.01); again, the greater than 3.00 threshold is categorized as highachieving in this study. A Mann-Whitney $U$ test was also utilized to determine if the population distribution of the number of HIPs were equal between high-achievers and their peers; a Mann-Whitney $U$ test is the nonparametric alternative to an independent samples T-test. IBM SPSS Statistics 22 (IBM Corporation, 2014) was utilized to analyze the data and the alpha level was set at .05. 


\section{Results}

High-Achieving vs Non-High-Achieving Peers

Relating to the number of HIPs, a Mann-Whitney $U$ test indicated that the population distributions were different for high-achieving African American students and their non-high-achieving peers, $Z=-2.950, p=.003$. Figure 1 displays the percent of high-achievers versus those at or below a 3.0 GPA based on the number of HIPs they have participated in. Generally, as students participated in more HIPs, a greater percentage of African American students possessed a GPA of greater than 3.00.

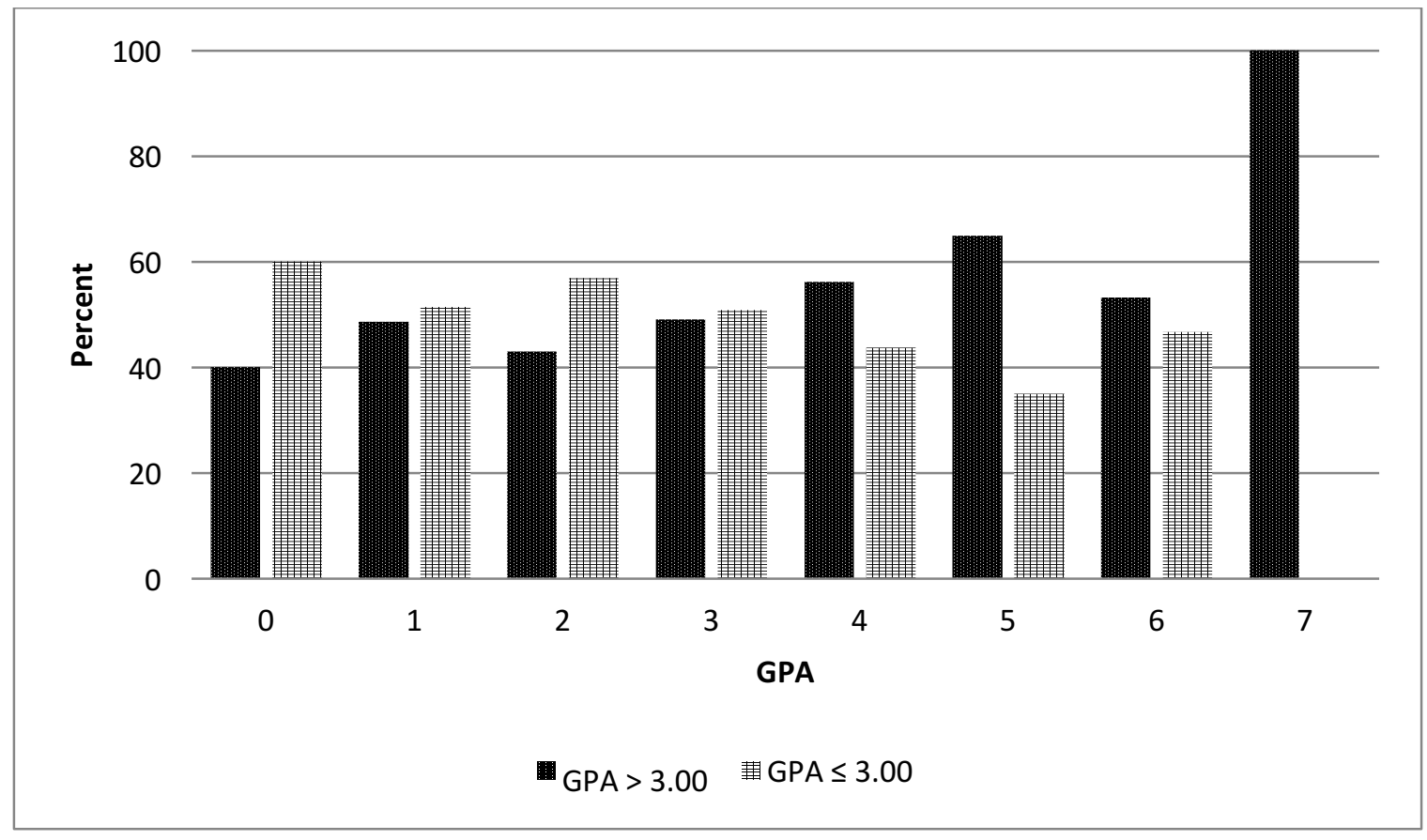

Figure 1. HIPs and High Academic Achievement. Bar graph showing as students participated in more HIPs, a greater percentage of African American students possessed a GPA of greater than 3.00. The researchers urge caution in interpreting the impact of involvement in seven HIPs since only four students participated in all HIPs included in the study. 
Journal Committed to Social Change on Race and Ethnicity | 2017

\section{First-Year and Second-Year Students}

Relating to the type of involvement in HIPs, table 1 displays chi-square statistics related to involvement in select HIPs for first-year and second-year college students. Data suggest that involvement in collaborative assignments and projects was statistically associated with academic high achievement for underclass African American college students, $X^{2}(1, N=313)=5.942, p=.015 ; 57 \%$ of students that have participated in collaborative assignments and projects were high achievers compared to $42.7 \%$ of students that had not participated in the HIP.

Table 1. Experiences in Select HIPS for First-year and Second-year African American Students

\begin{tabular}{lllll}
\hline High-Impact Practice & DF & $\mathrm{N}$ & $\mathrm{X}^{2}$ & $\mathrm{p}$-value \\
\hline First-year Seminars/Experiences & 1 & 313 & 2.723 & .099 \\
Internships & 1 & 313 & .587 & .444 \\
Writing-intensive Courses & 1 & 313 & .123 & .726 \\
Collaborative Assignments and Projects* & 1 & 313 & 5.942 & .015 \\
Diversity/Global Learning & 1 & 313 & .151 & .698 \\
Service Learning/Community-based Learning & 1 & 313 & .068 & .794 \\
Undergraduate Research & 1 & 313 & .194 & .660 \\
\hline
\end{tabular}

Note. ${ }^{*} p<.05$

\section{Juniors and Seniors}

Table 2 displays chi-square statistics related to involvement in select HIPs for African American college juniors and seniors. Data suggest there is an association between involvement in writing-intensive courses and academic high achievement for upper-class African American college students, $X^{2}(1, N=339)=5.915, p=.015 ; 56.2 \%$ of upper-level students who had been involved in writing-intensive courses were high achievers compared to $42.6 \%$ who had not been involved in the HIP. Further, data suggest there is an association between participation in diversity/global learning and academic high achievement for upper-class African American college students, $\mathrm{X}^{2}(1, N$ 
$=339)=4.145, p=.042 ; 61.2 \%$ of upper-level students who had been involved in diversity or global learning experiences were high achievers compared to only $45.5 \%$ who had not been involved in the activity. Data also suggest there is an association between involvement in undergraduate research and academic high achievement for upper-class African American college students, $X^{2}(1, N=339)=6.735, p=.009 ; 59.8 \%$ of upper-level students who had been involved in undergraduate research were high achievers compared to only $43.7 \%$ who had not been involved in the HIP.

Table 2. Experiences in Select HIPs for Junior and Senior African American Students

\begin{tabular}{lllll}
\hline High-Impact Practice & DF & $\mathrm{N}$ & $\mathrm{X}^{2}$ & $\mathrm{p}$-value \\
\hline First-year Seminars/Experiences & 1 & 339 & 2.265 & .132 \\
Internships & 1 & 339 & 1.354 & .245 \\
Writing-intensive Courses $^{*}$ & 1 & 339 & 5.915 & .015 \\
Collaborative Assignments and Projects $_{\text {Diversity/Global Learning }}^{*}$ & 1 & 339 & 3.318 & .069 \\
Service Learning/Community-based Learning $^{*}$ & 1 & 339 & 4.145 & .042 \\
Undergraduate Research* $^{*}$ & 1 & 339 & .503 & .478 \\
\hline
\end{tabular}

Note. ${ }^{*} p<.05$

\section{Gender Identity}

Table 3 displays results relating to involvement within HIPs and gender identity for African American college students. Results suggest there is an association between gender identity and involvement in Service Learning/Community-Based Learning, $X^{2}(1$, $N=648)=4.948, p=.026$. Specifically, women $(42.3 \%)$ were more likely to participate in this HIP compared to men (32.2\%) for the sample. Beyond the aforementioned finding, men and women participated in additional HIPs at statistically similar rates. 
Table 3. Experiences in Select HIPs for Men and Women

\begin{tabular}{lllll}
\hline High-impact Practice & DF & $N$ & $\mathrm{X}^{2}$ & p-value \\
\hline First-year Seminars/Experiences & 1 & 648 & .330 & .566 \\
Internships & 1 & 648 & 1.009 & .315 \\
Writing-intensive Courses & 1 & 648 & 1.977 & .160 \\
Collaborative Assignments and Projects & 1 & 648 & 1.422 & .233 \\
Diversity/Global Learning & 1 & 648 & 1.017 & .313 \\
Service Learning/Community-based Learning* & 1 & 648 & 4.948 & .026 \\
Undergraduate Research & 1 & 648 & 1.207 & .272
\end{tabular}

Note. ${ }^{*} p<.05$

\section{Discussion}

Based on the sample included in this study, we found that the nature, volume, and class standing of African American college students involved in HIPs is associated with GPA. As the number of HIPs students were involved in increased, the likelihood of possessing a GPA greater than 3.00 also increased. Yet, the majority of students possessing GPAs of greater than 3.00 only became true once students experienced the cumulative effect of participating in four or more HIPs. This finding highlight that the volume of HIPs is positively associated with a GPA greater than 3.00. When exploring HIPs by class standings these findings became more complex.

For students in their first or second year of college, involvement in collaborative assignments was associated with a GPA greater than 3.00. For juniors and seniors, writing intensive courses, diversity/global experiences (e.g., study abroad), and undergraduate research opportunities were all associated with a GPA greater than 3.00. Subsequently, as Kuh (2008) suggests that HIPs are important to engage students and foster deep learning, the present study adds to the literature by documenting when African American students participate in HIPs mattered for the students included in the 
Journal Committed to Social Change on Race and Ethnicity | 2017

study. Further, this study highlights certain types of HIPs that were meaningful to high academic achievement for African American college students during their progression towards a degree. Collectively, the complexities of these findings regarding volume, time, and type of HIP are effective for African American students warrant greater attention.

As Nora, Cabrera, Hagedorn, and Pascarella (1996) documented that GPA is directly related to persistence to graduation for students of color, one might suggest engaging African American students in collaborate assignments during their first two years is important for their GPAs and persistence. We question what this finding means for the population, given what existing literature has documented about African American college students. For example, Steele (2010) found African American students spend more time studying alone due to what he coined stereotype threat, "the threat of being viewed through the lens of a negative stereotype, or the fear of doing something that would inadvertently confirm that stereotype" (Steele, 1999, p. 46). The findings are either inconsistent with Steele's recommendation or suggest the finding confirms Steele's assertion as participating in collaborative assignment might force a student to put more time and energy into group projects in order to dispel stereotypes about African Americans and should be further explored.

While scholars have noted the importance of peer relationships as a critical component of a student's undergraduate studies (e.g., see Booker, 2007; Dennis, Phinney, \& Chuateco, 2005; Harper, 2005), we found that Collaborative Assignments and Projects—which are different from peer relationships yet still relational—were critical for the participants. Ultimately, the first-year and second-year students in this 
study highlight the importance of peer interactions, but highlight an academic component that was salient for the participants: Collaborative Assignments and Projects. For juniors and seniors, Writing-Intensive Courses, Diversity/Global Learning, and Undergraduate Research were statistically associated with GPA. Like the findings for first-year and second-year students, these findings highlight the importance of academic engagement. These findings also highlight the importance of developing and sustaining faculty relationships. Littleton (2002) describes faculty involvement as critical in persistence, and Fischer (2007) found African Americans often have closer ties to faculty than their racial/ethnic peers. As faculty often serve as mentors for undergraduate research, group study abroad opportunities, and writing intensive courses, the findings for this population reinforce the need for students to develop strong relationships with faculty early in the semester, but goes further by documenting certain activities for African American students during their third and fourth years.

In terms of gender identity, we found that women in this study were involved more than men in Service Learning/Community-Based Learning and did not find any statistically significant differences for other high-impact practices. Like Harper, Carini, Bridges, and Hayek (2004), we found that women are just as engaged as men on campus, and sometimes more engaged in certain activities, although their study focused on African American students at historically Black colleges and universities. As Chavous (2002) highlighted:

The fact that African American males are represented less in higher education than:

females is one of no small importance. However, the processes related to these differential outcomes have been less explored, and thus, the ways that race and 
Journal Committed to Social Change on Race and Ethnicity | 2017

gender interact to influence college outcomes in PWI settings are not clear. (pp. 142-143)

Our findings support Chavous's call as we found African American men and women might be involved differently at predominantly White institutions and their varied involvement by (non-)gender identities for African American students warrant further investigation.

Overall, the findings of this study mirror Myrick, DeSousa, and Mitchell's (2015) findings, as they explored the influence of high-impact practices for students at a historically Black institution during their transition from the first to second year and from senior year to graduation. Seniors in their study reinforce the importance of facultystudent relationships and enriching educational experiences, and our findings, again, offer some insight as to what the nature of that involvement was for the students included in the present study.

\section{Limitations}

Although the research questions have been carefully addressed, no research is without limitations. First, the data did not account for the cumulative effect of involvement in the same high-impact practice overtime; therefore, it may be beneficial to incorporate questions about how many experiences one has had in individual highimpact practices during future studies. Second, inviting students to participate in the study results in a risk of selection bias; of utmost concern is the assumption that students who are more involved on campus may choose to participate in surveys at higher rates. Third, allowing students to self-report involvement in high-impact practices allows researchers to investigate when students believed they participated in certain activities, but individual definitions and beliefs may not always align with universally 
accepted definitions. Fourth, one must consider that female participation was slightly inflated as women account for approximately two-thirds of undergraduate enrollment among African American students across the United States (National Center for Education Statistics, 2016). Finally, the researchers caution generalizing these results to Historically Black Colleges and University, other minority-serving institutions, and baccalaureate colleges since the sample attended master's and doctoral-granting institutions and six of the institutions were predominantly White institutions.

\section{Suggested Practice}

Using the findings from this study, we offer the following practice. Institutions often support HIPs generally rather than suggesting certain HIPs for certain groups, suggesting when these groups should be involved, and suggesting how this might be

tied to the students that they admit. Just as Myrick, DeSousa, and Mitchell (2015) found that certain HIPs mattered for first-to-second-year retention and for senior-year to graduation retention at a historically Black college, so we found quality and quantity mattered for the population included in the study. Practitioners should recognize that certain HIPs might prove useful for campuses as they work to retain and graduate their students rather than generalizing the importance for HIPs.

\section{Implications for Future Research}

While the findings included in this study add to the literature, there are additional ways this research could be advanced for African American students and initiated for other populations. First, predictive studies using more advanced statistical analytic methods to study HIPs that influence college GPA for African American students may prove beneficial (e.g., multilevel linear modeling and regression). In tandem, qualitative 
studies on the quality and reasons why the HIPs in this study mattered would offer reasons why students in this sample carried a GPA greater than 3.00 more often when involved in the HIPs. These studies help contextualize and advance some of the questions we were left with during the discussion.

Second, given we found that the nature, volume, and time of HIPs mattered for African American students, studies investigating how these findings might change for other underrepresented and unique populations (e.g., first-generation college, lowincome, lesbian, gay, and bisexual, international students) might be explored. Third, studies exploring how a replication of the present study using a larger sample size that is more representative of African American students across the nation confirm these findings, reject these findings, or suggest other HIPs are important, too. In sum, this study documents the association of involvement with a GPA greater than 3.00 for African American students. This reinforces the notion that interventions and strategies for students should be customized for students (Soria, Gipson, \& Mitchell, 2015), even beyond racial/ethnic interventions, as researchers and practitioners know all students are not the same; however, one thing that is the same for all students-they each deserve support informed by who they are. 


\section{References}

ACT. (2011). The condition of college \& career readiness: 2011. Retrieved from www.act.org/readiness/2011

Astin, A. W. (1984). Student involvement: A developmental theory of higher education. Journal of College Student Personnel, 25(4), 297-308.

Astin, A. W. (1999). Student involvement: A developmental theory of higher education. Journal of College Student Development, 40(5), 518-529.

Bonner, F. A., II. (2010). Academically gifted African American male college students. Santa Barbara, CA: Praeger.

Booker, K. C. (2007). Perceptions of classroom belongingness among African American college students. College Student Journal, 41(1), 179-186.

Chickering, A. W., \& Gamson, Z. F. (1999). Development and adaptations of the seven principles for good practice in undergraduate education. New Directions for Teaching and Learning, 80, 75-81.

Chavous, T. M. (2002). African American college students in predominantly White institutions of higher education: Considerations of race and gender. African American Research Perspectives, 8(1), 142-150.

Choy, S. P. (2001). Students whose parents did not go to college: Postsecondary access, persistence, and attainment. Washington, DC: U.S. Department of Education.

Cole, D. (2011). Debunking anti-intellectualism: An examination of African American college students' intellectual self-concepts. Review of Higher Education, 34(2), 259-282.

Cuyjet, M. J. (2006). African American college men: Twenty-first century issues and concerns. In M. J. Cuyjet (Ed.), African American men in college (pp. 3-23). San Francisco, CA: Jossey-Bass.

DeAngelo, L., Franke, R., Hurtado, S., Pryor, J. H., \& Tran, S. (2011). Completing college: Assessing graduation rates at four-year institutions. Los Angeles: University of California Los Angeles, Higher Education Research Institute.

Dennis, J. M., Phinney, J. S., \& Chuateco, L. I. (2005). The role of motivation, parental support, and peer support in the academic success of ethnic minority firstgeneration college students. Journal of College Student Development, 46(3), 223236.

Finley, A., \& McNair, T. (2013). Assessing underserved students' engagement in highimpact practices. Washington, DC: American Association of Colleges and Universities.

Fischer, M. J. (2007). Settling into campus life: Differences by race/ethnicity in college involvement and outcomes. Journal of Higher Education, 78(2), 125-156.

Fries-Britt, S., \& Griffin, K. A. (2007). The Black box: How high-achieving Blacks resist stereotypes about Black Americans. Journal of College Student Development, 48(5), 509-524.

Griffin, K. (2006). Striving for success: A qualitative exploration of competing theories of high-achieving Black college students' academic motivation. Journal of College Student Development, 47(4), 384-400. 
Guiffrida, D. A. (2004a). Friends from home: Asset and liability to African American students attending a predominately White institution. NASPA Journal, 41(3), 693708.

Guiffrida, D. A. (2004b). How involvement in African American student organizations supports and hinders academic achievement. NACADA Journal, 24(1\&2), 88-98.

Guiffrida, D. A. (2006). Toward a cultural advancement of Tinto's theory. Review of Higher Education, 29(4), 451-472. doi: 10.1353/rhe.2006.0031

Harper, S. R. (2005). Leading the way: Inside the experiences of high-achieving African American male students. About Campus, 10(1), 8-15. Harper, S. R. (2008). Realizing the intended outcomes of Brown: High-achieving African American male undergraduates and social capital. American Behavioral Scientist, 51(7), 10301053.

Harper, S. R. (2012). Black male student success in higher education: A report from the national Black male college achievement study. Philadelphia: University of Pennsylvania, Center for the Study of Race and Equity in Education.

Harper, S. R., Carini, R. M., Bridges, B. K., \& Hayek, J. C. (2004). Gender difference in student engagement among African American undergraduates at historically Black colleges and universities. Journal of College Student Development, 45(3), 271284.

Harper, S. R., \& Griffin, K. (2011). Opportunity beyond affirmative action: How lowincome and working-class Black male achievers access highly selective, high-cost colleges and universities. Harvard Journal of African American Public Policy, 17, 43-60.

Harper, S. R., \& Quaye, S. J. (2007). Student organizations as venues for Black identity expression and development among African American male student leaders. Journal of College Student Development, 48(2), 127-144.

Hu, S., \& St. John, E. P. (2001). Student persistence in a public higher education system: Understanding racial and ethnic differences. Journal of Higher Education, 72(3), 265-286.

IBM Corporation. (2014). SPSS 22.0. Chicago, IL: Author.

Kuh, G. (2008). High-impact practices: What they are, who has access to them, and why they matter. Washington, DC: American Association of Colleges and Universities.

Kuh, G. D., Kinzie, J., Schuh, J. H., Whitt, E. J., \& Associates. (2010). Student success in college: Creating conditions that matter. San Francisco, CA: Jossey-Bass.

Landis, J. R., \& Koch, G. G. (1977). The measurement of observer agreement for categorical data. Biometrics, 33(1), 159-174.

Littleton, R. A. (2002). Campus involvement among African American students at small, predominately white colleges. College Student Affairs Journal, 21(2), 53-67.

Mauk, A. J., \& Jones, W. A. (2006). African American students. In L. A. Gohn \& G.R. Albin (Eds.), Understanding college student subpopulations: A guide for student affairs professionals (pp. 69-90). Washington, DC: National Association of Student Personnel Administrators.

Myrick, M., DeSousa, D. J., \& Mitchell, D., Jr. (2015). National survey of student engagement findings at a historically Black institution: Does student engagement impact persistence? In D. Mitchell, Jr., K. Soria, E. Daniele, \& J. Gipson (Eds.), 
Student involvement \& academic outcomes: Implications for diverse college student populations. New York, NY: Peter Lang.

National Center for Educational Statistics (2016). Total fall enrollment in degreegranting postsecondary institutions, by level of enrollment, sex, attendance status, and race/ethnicity of student: Selected years, 1976 through 2014. Retrieved from https://nces.ed.gov/programs/digest/d15/tables/dt15_306.10.asp?current=yes.

Nora, A., Cabrera, A., Hagedorn, L. S., \& Pascarella, E. (1996). Differential impacts of academic and social experiences of college-related behavioral outcomes across different ethnic and gender groups at four-year institutions. Research in Higher Education, 37(4), 427-451.

Nora, A., Barlow, E., \& Crisp, G. (2005). Student persistence and degree attainment beyond the first year in college: The need for research. In A. Seidman (Ed.), College student retention: Formula for success (pp. 129-154). Westport, CT: Praeger.

Pascarella, E. T., \& Terenzini, P. T. (2005). How college affects students: A third decade of research ( $2^{\text {nd }}$ ed. $)$. San Francisco, CA: Jossey-Bass.

Rovai, A. P., Gallien, Jr., L. B., \& Wighting, M. J. (2005). Cultural and interpersonal factors affecting African American academic performance in higher education: A review and synthesis of the research literature. Journal of Negro Education, 74(4), 359-370.

Smith, M. J. (2009). Right directions, wrong maps: Understanding the involvement of low-SES African American parents to enlist them as partners in college choice. Education and Urban Society, 41(2), 171-196. doi: 10.1177/00131245 08324028.

Soria, K., Gipson, J., \& Mitchell, D., Jr. (2015). Introduction. In D. Mitchell, Jr., K. Soria, E. Daniele, \& J. Gipson (Eds.), Student involvement \& academic outcomes: Implications for diverse college student populations (pp. 1-8). New York, NY: Peter Lang.

Steele, C. M. (1999, August). Thin ice: "Stereotype threat" and Black college students. The Atlantic Monthly, 284, 44-47, 50-54.

Steele, C. M. (2010). Whistling Vivaldi: And other clues to how stereotypes affect us. New York, NY: W. W. Norton.

Sutton, E. M., \& Kimbrough, W. M. (2001). Trends in Black student involvement. NASPA Journal, 39(1), 30-40.

Thomas, S. P., Thompson, C., Pollio, H. R., Greenberg, K., Conwill, W., Sall, A., Klukken, G., Davis, M. W., \& Dias-Bowie, Y. (2007). Experiences of struggling African American students at a predominantly White institution. Research in Schools, 14(2), 1-17.

Tinto, V. (1975). Dropout from higher education: A theoretical synthesis of recent research. Review of Educational Research, 45(1), 89-125.

Tinto, V. (2006-2007). Research and practice of student retention: What's next? Journal of College Student Retention, 8(1), 1-19.

Vargas, J. H. (2004). College knowledge: Addressing information barriers to college. Boston, MA: Education Resource Institute.

Wilson, V. W. (2007). On equal ground: Causes and solutions for lower college completion rates among Black males. In National Urban League (Ed.), The state of 
Journal Committed to Social Change on Race and Ethnicity | 2017

Black America 2007: Portrait of the Black male (pp. 123-131). New York, NY: Beckham. 